\title{
BUSINESS PERFORMANCE ANALYSIS OF AGRICULTURAL ENTREPRENEUR-BASED CHRYSANTHEMUM FARMERS IN BANDUNGAN SUB-DISTRICT, SEMARANG REGENCY OF INDONESIA
}

\author{
Supatmi Retna* \\ Master's Program of Agribusiness, Faculty of Animal and Agricultural Sciences, \\ University of Diponegoro, Semarang, Indonesia
}

Setiadi Agus, Mukson

Faculty of Animal and Agricultural Sciences, University of Diponegoro, Semarang, Indonesia

$$
\text { *E-mail: retnabila26@gmail.com }
$$

\begin{abstract}
The purpose of this study was to determine the effect of internal and external factors on entrepreneurial behavior, to determine the effect of entrepreneurial behavior on business performance, and to determine the direct influence of external factors on the business performance of chrysanthemum farmers in Bandungan Sub-district, Semarang Regency. The location determination method uses purposive sampling with a total sample of 120 respondents. Data collection methods used in this study are observation and interviews with the help of questionnaires. Data were taken in the form of primary and secondary data, and the parameters in this study were internal factors (X1), external factors (X2), entrepreneurial behavior $(\mathrm{Y})$, and business performance $(\mathrm{Z})$. Data analysis method used path analysis using SPSS 20 Software. The results showed that there were significant influences $(P \leq 0.005)$ of internal and external factors on entrepreneurial behavior, entrepreneurial behavior on business performance, and the direct influence of external factors on the business performance of chrysanthemum farmers. The relationship model of farm business performance has a real influence on the entrepreneurship of chrysanthemum flower farming in Bandungan Sub-district, Semarang Regency.
\end{abstract}

\section{KEY WORDS}

Performance, entrepreneurial behavior, chrysanthemums, public service.

The ornamental plant industry (floriculture industry) in Indonesia has considerable development prospects. This development can be seen by the high production of ornamental plant which shows an increasing increase every year. One type of ornamental plant that is widely cultivated because of the high demand is chrysanthemum flowers. Chrysanthemum production has increased in line with high consumer demand. The Directorate General of Horticulture at the Indonesian Ministry of Agriculture (2018) stated there was an increase in national chrysanthemum production for five years from 2014 to $9,647,827 / \mathrm{m}^{2}$ to $11,099,276 / \mathrm{m}^{2}$ in 2018. The largest chrysanthemum producing area in Central Java is Bandungan Sub-district in Semarang Regency which has a production contribution of 98.68\%. In addition to production, chrysanthemum flowers in Semarang Regency are also used as tourist sites. Chrysanthemum production in 2016 (120 million stalks) increased significantly from 2015 (100 million stalks). The increase in production was influenced by the opening of chrysanthemum agro-tourism in Semarang Regency. Because chrysanthemums are used as agritourism, the treatment is optimal. The increase in production was influenced by the increasing business performance of chrysanthemum farmers and the growth several farmers' entrepreneurial spirits. Ren et al. (2019) state that the performance of agricultural businesses and agricultural land area has an influence, where the better performance will be able to increase the area of agricultural business land. Alem et al. (2018) in their research stated that good performance will be able to influence the socio-economy and sustainability of farmers' businesses. 
Chrysanthemum flower farmers in Bandungan Sub-district, Semarang Regency, generally still see the holistic prospect of developing chrysanthemum flowers. The assumption of chrysanthemum cultivation as a side business besides planting vegetables is still so attached, that the performance of chrysanthemum farmers is not yet optimal. Two factors that influence the performance of chrysanthemum farmers are internal factors originating from within individual farmers and external factors originating from outside such as group influence, counseling, price stability and information, and marketing access. Rehman et al. (2008) state that the role of agricultural extension is crucial in providing advice and input to farmers. In addition, that extension workers have the ability to know the typology of each human resource they face. The business strategy owned by farmers is also relatively low and it is still difficult to meet the sustainability of consumer demand so that it affects the selling price of chrysanthemum flowers. Repetition of economic transactions occurs because of social relationship from producers to consumers so that it can expand sales volumes (Anh and Bokelmann, 2019). Both internal and external factors can influence the business performance of chrysanthemum farmers. Tuchitech and Lee (2018) state that internal, external, social, and economic factors can influence the performance of agricultural development.

One aspect that is interconnected in chrysanthemum cultivation in addition to business performance is entrepreneurial behavior. Generally, there are still only few Chrysanthemum farmers who have entrepreneurial behavior. Entrepreneurial behavior is useful for creating added value by combining all economic resources through new and different ways to win competition. Indirectly, entrepreneurial behavior has an effect on business performance. Ariesa et al. (2014) and Saragih et al. (2019) Ariesa et al. (2014) and Saragih et al. (2019) in their research stated that entrepreneurial behavior has a significant influence on business performance, but is not a dominant factor in agricultural business, so increasing entrepreneurial behavior will improve farmers' business performance. The purpose of this study was to determine the influence of internal and external factors on entrepreneurial behavior, to determine the influence of entrepreneurial behavior on business performance, and to determine the direct influence of external factors on the business performance of chrysanthemum farmers in Bandungan Sub-district, Semarang Regency.

\section{MATERIALS AND METHODS OF RESEARCH}

The research was performed in Bandungan Sub-district, Semarang Regency. The location of the study was chosen because it is the largest chrysanthemum production center in Semarang Regency and Central Java Province. The population of chrysanthemum farmers in the Bandungan Sub-district is as many as 173 people with land area ownership of $\geq 900 \mathrm{~m}^{2}$. Determination of the number of samples of research respondents was using the Slovin formula so that 120 respondents were obtained. The calculation of the number of sample respondents is:

$$
n=\frac{N}{1+N e^{2}}
$$

Data collection methods used in this study were observation and direct interviews with respondents - the chrysanthemum farmers. The data used in this study consisted of primary and secondary data. Primary data were obtained by observing and interviewing respondents directly with the help of a questionnaire, while secondary data were the data obtained from institutions or related agencies.

The variables observed in this study consisted of independent variables of internal factors (X1) and external factors (X2), intervening variables of entrepreneurial behavior (Y), and dependent variables of business performance (Z). Each indicator of the research variables is presented in Table 1 . Analysis of business performance of chrysanthemum farmers from each variable uses a Likert scale with five categories. To identify the functional relationship of each research variable, it is presented in Figure 1. 


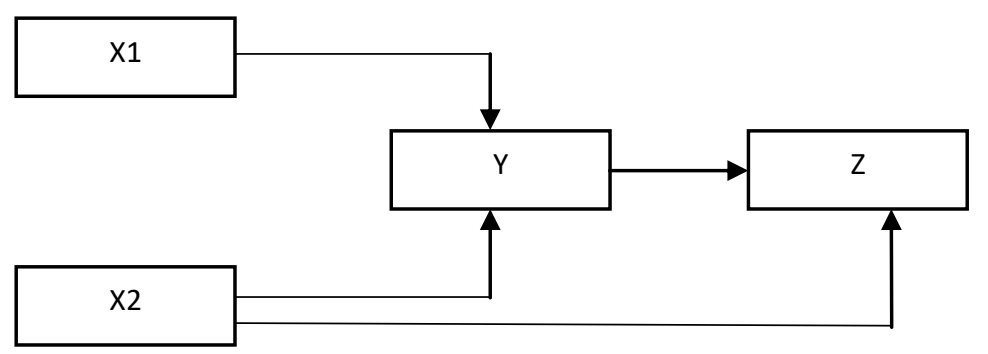

Figure 1 - Relationship Model of Internal Factors, External Factors, and Entrepreneurial Behavior of Chrysanthemum Farmers to Business Performance

Causal relationships between research variables can be formulated mathematically in the form of the following equation:

$$
\begin{aligned}
Y= & b_{1} X_{1}+b_{2} X_{2}+e \\
& Z=b_{1} X_{1}+b_{2} X_{2}+b_{3} X_{2}+b_{4} Y+e
\end{aligned}
$$

Where: $X_{1}=$ Internal factors; $X_{2}=$ External factors; $Y=$ entrepreneurial behavior; $\mathrm{Z}=$ Business performance; $\mathrm{e}=$ Error .

The multilevel relationship model between variables was analyzed using the Path Analysis method using SPSS 20 . The validity and reliability tests were performed to determine the reliability of the questionnaire used. The classical assumption test fulfills the regression requirements so that the conclusions produced are in line with the objectives of the study.

\begin{tabular}{|c|c|}
\hline Research variables & Indicators \\
\hline \multirow[t]{8}{*}{ Internal factors (Independent variable $\mathrm{X}_{1}$ ) } & Business capital ownership \\
\hline & Ownership of production infrastructure \\
\hline & Entrepreneurial motivation \\
\hline & Perception of business \\
\hline & The desire to farm \\
\hline & Willingness to receive information \\
\hline & Willingness to accept cultivation technology \\
\hline & Willingness to socialize in farmer groups \\
\hline \multirow[t]{8}{*}{ External Factors (Independent variable $\mathrm{X}_{2}$ ) } & Input material availability \\
\hline & Counseling and training support \\
\hline & Infrastructure availability \\
\hline & Solidarity among chrysanthemum farmers \\
\hline & Access to market information \\
\hline & Access to information technology \\
\hline & The existence of supporting business groups \\
\hline & Price stability \\
\hline \multirow[t]{5}{*}{ Entrepreneurial Behavior (Intervening Variable Y) } & Perseverance \\
\hline & Being responsive to opportunities \\
\hline & Innovative \\
\hline & Courage in taking risks \\
\hline & Being independent \\
\hline \multirow[t]{6}{*}{ Business performance ( $Z$ dependent variable) } & Increased revenue \\
\hline & Competitive advantage \\
\hline & Business Up Scale \\
\hline & Increase in sales value \\
\hline & Quality improvement \\
\hline & Productivity Improvement \\
\hline
\end{tabular}

Table 1 - Research Variables

\section{RESULTS AND DISCUSSION}

Respondents in this study were 120 farmers who cultivated chrysanthemum plant. Aspects of the identity of the respondents in this study were gender, age, level of education, as well as chrysanthemum planting time which can be seen in Table 2.

Respondents were dominated by 119 males and there was 1 female. Most respondents were between $31-40$ years old with a percentage of $42.50 \%$. 
The chrysanthemum farmers' level of education varied, as many as $43.33 \%$ of respondents had Elementary school level, 36.67\% completed Junior High School, 17.50\% graduated High School education, $0.83 \%$ graduated from Vocational High School and 1.67\% were Bachelor graduates. Fielke and Bardsley (2014) and Paltasingh and Goyari (2018) stated that the level of education contributed to increasing capacity in adapting information and being able to increase production of agricultural products.

Table 2 - Characteristics of research respondents

\begin{tabular}{llll}
\hline \hline No. & Respondent's identity & Number & Percentage \\
\hline 1 & Gender & $\ldots$ Pax... & $\ldots \%$ \\
& Male & 119 & 99.17 \\
& Female & 1 & 0.83 \\
\hline 2. & Age (years old) & & \\
& $20-30$ & 12 & 10.00 \\
& $31-40$ & 51 & 42.50 \\
& $41-50$ & 35 & 29.17 \\
& $51-60$ & 12 & 10.00 \\
& $\geq 61$ & 10 & 8.33 \\
\hline 3. & Level of Education & & \\
& SD & 52 & 43.33 \\
& SMP & 44 & 36.67 \\
& SMA & 21 & 17.50 \\
& STM & 1 & 0.83 \\
& S1 & 2 & 1.67 \\
\hline 4. & Farming Experience & & \\
& $1-5$ & 52 & 43.33 \\
& $6-10$ & 41 & 34.17 \\
& $11-15$ & 16 & 13.33 \\
& $16-20$ & 6 & 5.00 \\
& $\geq 21$ & 5 & 4.17 \\
\hline
\end{tabular}

The length of chrysanthemum farming was different for each farmer, with as many as $43.33 \%$ of respondents had $1-5$ years of farming, $34.17 \%$ of respondents had $6-10$ years of farming experience, $13.33 \%$ of respondents had long experience of farming of between 1115 years, $5 \%$ of respondents have $16-20$ years of farming experience, and as much as $4.17 \%$ of respondents have experience of farming of $\geq 21$ years. Chrysanthemum farming experience will affect the performance of farmers in addressing various dynamics in chrysanthemum farming as their daily livelihood.

Regression Model $\mathrm{l}$. The linear regression equation is used to determine the effect of internal variables and external variables on the entrepreneurial behavior of chrysanthemum flower farmers. To identify the magnitude of the effect of internal and external variable models on entrepreneurial behavior variables, the results were presented in Table 3.

Table 3 - ANOVA Test Results

\begin{tabular}{llllll}
\hline Model & Sum of Squares & df & Mean Square & F & Sig. \\
\hline Regression & 1717.548 & 2 & 858.74 & 59.744 & $0.000^{\mathrm{b}}$ \\
Residual & 1681.777 & 117 & 14.374 & & \\
Total & 3399.325 & 119 & & \\
$R$ Square $=0.505$ & & & & \\
Adjusted $R$ Square $=0.497$ & & & & \\
Durbin-Watson $=1.899$ & & & & \\
\hline
\end{tabular}

The values of $X_{1}$ and $X_{2} R$ square show 0.505 or $50.5 \%$, respectively. This means that internal and external variables can explain $50.5 \%$ variation in changes in entrepreneurial behavior variables. The remaining $49.5 \%$ is explained by other variables not explained in the model in the study. 
ANOVA test results in Table 3 , which are the influence of internal and external variables on entrepreneurial behavior, the calculated $F$ value was 59.744 with a significant level of $0.000(P \leq 0.05)$ so that it can be concluded that all of the independent variables in the model, the internal and external variables, have an influence on the dependent variable of entrepreneurial behavior.

Table 4 - Test Results of Research Variable Models

\begin{tabular}{|c|c|c|c|c|c|}
\hline \multirow{2}{*}{ Model } & \multicolumn{2}{|c|}{ Unstandardized Coefficients } & \multirow{2}{*}{$\frac{\text { Standardized Coefficients }}{\text { Beta }}$} & \multirow[b]{2}{*}{$\mathrm{t}$} & \multirow{2}{*}{ Sig. } \\
\hline & $\mathrm{B}$ & Std. Error & & & \\
\hline (Constant) & 18.032 & 4.235 & & 4.258 & 0.000 \\
\hline Internal & 0.391 & 0.060 & 0.510 & 6.536 & 0.000 \\
\hline External & 0.206 & 0.056 & 0.288 & 3.694 & 0.000 \\
\hline
\end{tabular}

The research variable model in Table 4 shows that internal and external variables have a positive regression coefficient or are directly proportional to entrepreneurial behavior. This shows that internal and external variables will have a positive influence on entrepreneurial behavior. The regression equation of internal and external variables for entrepreneurial behavior is as follows:

$$
Y=0,510 X_{1}+0,288 X_{2}
$$

The partial influence of each independent research variable, the internal and external variables, can be seen from the internal variable's significance result of $p$-value 0.000 , because the $p$-value is smaller than the significance set at $0.05(0.000 \leq 0.05)$ can be concluded that internal variables have an influence and are significant on entrepreneurial behavior. Internal factors can influence the growth of small businesses starting from the growth of entrepreneurial behavior of their owners (Rizal et al., 2017).Windirah et al. (2017) state that internal factors such as perceptions for entrepreneurship, education, and experience can improve entrepreneurial behavior. Doris et al. (2013) added that the willingness to accept all information will be able to affect one's entrepreneurial spirits and business. Rostiana and Fatahilah (2016) state that internal factors have a significant influence on harvests and product sales.

The external variable's significance $p$-value was 0.000 .The $p$-value was smaller than the significance set at $0.05(0.000 \leq 0.05)$. This means that the external variable has an influence and is significant on entrepreneurial behavior. Pearce and Robinson (2011) explain that the external factors externally influence a business in determining the direction and actions to be taken by the company. Indicators of external factors such as solidarity between entrepreneurs and the conditions of the surrounding environmental norms and performance based on local culture influence a person's entrepreneurial behavior (Seo et al., 2019). This external factor is also able to motivate someone to start a new business and bring up an entrepreneurial spirit (Fereidouniet al., 2010).

Regression model II. The influence of internal, external, and entrepreneurial behavior models on business performance variables in the regression test was seen from the value of $R$ square in the coefficient of determination test as presented in Table 5, which aims to determine the extent to which the model's ability to describe and explain variable variations.

Table 5 - ANOVA Test Results of regression model II

\begin{tabular}{llllll}
\hline \hline Model & Sum of Squares & $d f$ & Mean Square & $F$ & Sig. \\
\hline$\quad$ Regression & 2389.163 & 3 & 796.388 & 98.013 & $0.000^{\mathrm{b}}$ \\
$\quad$ Residual & 942.537 & 116 & 8.125 & & \\
$\quad$ Total & 3331.700 & 119 & & \\
$R$ Square $=0.717$ & & & & \\
Adjusted $R$ Square= $=.710$ & & & & \\
Durbin-Watson $=1.968$ & & & & \\
\hline
\end{tabular}


The $\mathrm{R}$ square values of $\mathrm{X} 1, \mathrm{X} 2$, and $\mathrm{Y}$ were 0.717 or $71.7 \%$. The values mean that internal, external and entrepreneurial behavior variables can explain $71.7 \%$ of the variation in changes in business performance variables. The remaining $28.3 \%$ is explained by other variables not explained in the study.

ANOVA test in Table 5 simultaneously produces the results on the influence of internal variables, external variables and entrepreneurial behavior on business performance. The calculated $F$ value of 98.013 with a significance value in the calculation was 0.000 less than $0.05(\mathrm{P} \leq 0.05)$ so that it can be concluded that all independent variables in the model, i.e. internal, external, and entrepreneurial behavior affect the business performance variables.

To identify the partial effect of each research variable, the data can be seen in Table 6 . The following is the regression equation of internal and external variables and entrepreneurial behavior on business performance:

$$
Z=0,467 X_{1}+0,361 X_{2}+0,152 Y
$$

Table 6 - Test results of the regression model II

\begin{tabular}{|c|c|c|c|c|c|}
\hline \multirow{2}{*}{ Model } & \multicolumn{2}{|c|}{ Unstandardized Coefficients } & \multirow{2}{*}{$\begin{array}{c}\text { Standardized Coefficients } \\
\text { Beta }\end{array}$} & \multirow{2}{*}{$\mathrm{T}$} & \multirow{2}{*}{ Sig. } \\
\hline & $\mathrm{B}$ & Std. Error & & & \\
\hline (Constant) & 5.828 & 3.422 & & 1.703 & 0.091 \\
\hline Internal & 0.355 & 0.053 & 0.467 & 6.752 & 0.000 \\
\hline External & 0.256 & 0.044 & 0.361 & 5.774 & 0.000 \\
\hline Entrepreneurial Behavior & 0.151 & 0.070 & 0.152 & 2.172 & 0.032 \\
\hline
\end{tabular}

The regression equation shows that the internal, external, and entrepreneurial behavior variables have a positive regression coefficient. This shows that the internal, external, and entrepreneurial behavior variables will have a positive influence on business performance. Partially seen from the significance value of internal, external, and entrepreneurial behavior variables, they have a probability of $(P \leq 0.05)$, so that each variable has a significant influence on business performance. An individual's entrepreneurial behavior can affect the performance of the company they lead, so attitude control is needed so that it has a positive effect on performance (Yazeed and Ringim, 2016). Barazandehet al. (2015) state that the spirits of entrepreneurship can be known from one's behavior and needs to be developed in order to increase their performance capacity. Lisa (2019) added that the spirits of entrepreneurship and innovation in organizations can improve the performance of micro and small businesses.

Path Analysis Model. The relationship model formed between independent variables consisting of internal factors $\left(X_{1}\right)$, external factors $\left(X_{2}\right)$, intervening variables $(Y)$, and dependent variables $(Z)$. As a whole, the model can be arranged as a relationship that affects each other as shown in Figure 2 below.

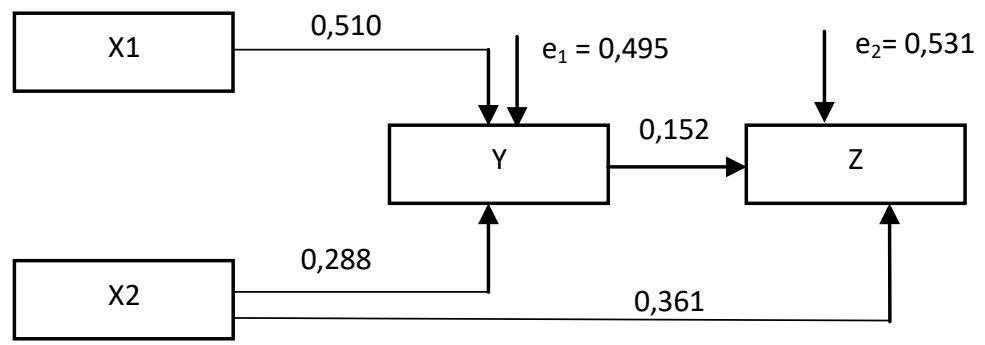

Figure 2 - Path analysis $\mathrm{X}_{1}, \mathrm{X}_{2}, \mathrm{Y}$ and $\mathrm{Z}$

The influence of $X_{1}$ through $Y$ on $Z$ is the indirect effect given by $X_{1}$ to $Z$, which is the multiplication of beta values $X_{1}$ to $Y$ with beta values of $Y$ on $Z$, i.e.: $0.510 \times 0.152=0.077$. Then, the indirect effect given by $X_{1}$ to $Z$ is 0.077 . The influence of $X_{2}$ through $Y$ on $Z$ is the 
indirect effect of $X_{2}$ on $Z$ through $Y$ obtained from the multiplication of beta values $X_{2}$ on $Y$ with beta values $Y$ on $Z$, i.e.: $0.288 \times 0.152=0.043$. The direct effect of $X_{2}$ on $Z$ was 0.361 . The total influence given by $X_{2}$ on $Z$ is $0.361+0.043=0.404$. These results can be interpreted that the indirect influence is smaller than the direct influence $(0.043 \leq 0.404)$. These results indicate that the indirect influence of the $X_{2}$ variable does not have a significant influence on Z variable.Dragnic (2014), Matyusz et al. (2015) stated that external factors influence the performance of micro and small businesses and are able to directly influence a business. External factors can also influence the income and profits of agricultural businesses (Lososova and Zdenek, 2014).

\section{CONCLUSION}

There is a significant influence between internal factors (ownership of business capital, ownership of production facilities, entrepreneurial motivation, perception of business, desire to farm, willingness to receive information, willingness to accept cultivation technology, and willingness to socialize farming groups) and external factors (availability of input materials, agricultural extension services and training, availability of infrastructure, solidarity among chrysanthemum farmers, access to market information, the existence of supporting business groups, and price stability) on the entrepreneurial behavior of chrysanthemum farmers in Bandungan Sub-district, Semarang Regency. There is a significant influence of entrepreneurial behavior (perseverance, responsiveness to opportunities, innovative, courage in taking risks, and being independent) on the performance of chrysanthemum business in Bandungan Sub-district, Semarang Regency. There is a direct and significant influence between external variables and chrysanthemum business performance in Bandungan Sub-district, Semarang Regency.

\section{REFERENCES}

1. Alem, H., G. Lien and J. B. Hardaker .2018. Economic performance and efficiency determinants of crop-producing farms in Norway. Int. J. Prod. and Perform. Manage. 67(9):1418-1434.

2. Anh, N. H., and W. Bokelmann. 2019. Determinants of Smallholders' Market Preferences: The Case of Sustainable Certified Coffee Farmers in Vietnam. Sustainability 11:1-20.

3. Ariesa, F. N., R. Nurmalina, and W. B. Priatna. 2014. Pengaruh perilaku kewirausahaan terhadap kinerja usaha tani tembakau rakyat di Kabupaten Bojonegoro and Lamongan. Buletin tanaman tembakau, serat and minyak Industri 6(2).

4. Barazandeh, M., K.Parvizian, M. Alizadeh and S. Khosravi. 2015. Investigating the effect of entrepreneurial competencies on business performance among early stage entrepreneurs Global Entrepreneurship Monitor (GEM 2010 survey data). J. Global Entrep. Res. 5(18): 1-12.

5. Direktorat Jenderal Hortikultura Kementerian Pertanian Indonesia. 2018. Buku statistik tanaman hortikultura Indonesia 2018. Kementerian Pertanian Indonesia. Jakarta.

6. Doris, O. G., and K. Irena. 2013. The influence of personal and environmental factors on entrepreneurs' performance. Kybernetes 42(6): 906-927.

7. Dragnic, D. 2014. Impact of internal and external factors on the performance of fastgrowing small and meduim businesses. Management 19(1): 119-159.

8. Fereidouni, H. G., T. A. Masron, D. Nikbin and R. E. Amiri. 2010. Consequences of external environment on entrepreneurial motivation in Iran. Asian Academy Manage. J. 15(2): 175-196.

9. Fielke, S. J., and D. K. Bardsley. 2014. The importance of farmer education in South Australia. Land used policy 39:301-312.

10. Lisa, O. 2019. The Effect of Entrepreneurial Behavior and Organizational Innovation on MSMEs Performance. J. Ilmiah Bidang Akuntansi and Manajemen, Vol. 16(2): 160-172.

11. Lososová, J and R. Zdeněk. 2014. Key Factors Affecting the Profitability of Farms in the Czech Republic. Agris on-line Papers in Economics and Informatics. 6: 21-36. 
12. Matyusz, Z., K. Demeter, and C. Szigetvári. 2015. The impact of external market factors on operational practices and performance of companies.Society and Economy 34(1):7393.

13. Paltasingh, K. R., and P. Goyari. 2018. Impact of farmer education on farm productivity under varying technologies: case of paddy growers in India. Agric. and Food Econ. 6(7): 1-19.

14. Pearce, J., A. and R. B. Robinson. 2011. Strategic Management Formulation, Implementation, and Control, Twelfth Edition, McGrawHill, New York.

15. Ren, C., S. Liu, H. V. Grinsven, S. Reis, S. Jin, H. Liu, B. Gu. 2019. The impact of farm size on agricultural sustainability. J. Cleaner Prod. 220: 357-367.

16. Rehman, T., C. Garforth, K. McKemey, C. Yates and R. Rana. 2008. Farmers' behavioural inclinations and their influence on the anticipated response to the reform of the common agricultural policy in England. J. Farm Management 13(4): 1-29.

17. Rizal,O., Suhadak, M. M. Kholid. 2017. Analysis of the influence of external and internal environmental factors on business performance: a study on micro small and medium enterprises (MSMES) of food and beverage. Russ. J. Agri. Sci. 6(66):47-56.

18. Rostiana, E., and Y. F. Hilah. 2016. Internal and external factors affecting the size of paddy field sold. J. Ekonomi Pembangunan 17(2): 125-135.

19. Saragih, E., C., T. M. Prihtanti and Yuliawati. 2019. The Effect of Farmers' Entrepreneurial Behavior on Business Performance of PUAP Program in Pandawai Subdistrict, East Sumba Regency. J. Sust. Agric. 34(1): 43-54.

20. Seo, Y. W., and Y. H. Lee. 2019. Effects of internal and external factors on business performance of start-ups in South Korea: The engine of new market dynamics. Int. J. Eng. Business Manage. 11: 1-12.

21. Tuchitech, H., and M. Lee. 2018. Factors Affecting the Performance of Agricultural Project from the Perspectives of Agriculture Extension Workers (A Case Study of Malawi). J. Agric. Ext. and Community Develop. 25(2):111-120.

22. Yazeed, M and K. J. Ringim. 2016. The Effect of Entrepreneurial Skills on Organizational Performance of Small and Medium Scale Enterprises in Kaduna State. Journal of Research and Development Perspectives 5(1): 1-17.

23. Windirah, N., H. K. Suwarsinah and A. K. Adhi. 2015. The Influence of Internal and External Factors on Entrepreneurship Behaviour on Entrepreneur Woman (Case Study of Small and Medium Craftswoman Bogor City). Intl. J. Sci. and Res. 6(1):1693-1695. 